\title{
Active stress field in central Italy: a revision of deep well data in the Umbria region
}

\author{
Maria Teresa Mariucci, Paola Montone and Simona Pierdominici \\ Istituto Nazionale di Geofisica e Vulcanologia, Sezione di Sismologia e Tettonofisica, Roma, Italy
}

\begin{abstract}
In this area the active stress field from borehole breakout analysis shows a prevalent NE-SW extension, perpendicular to the main tectonic structures, in agreement with stress inferred from earthquake focal mechanisms and with the strain velocity field. A detailed analysis of active stress data allows us to infer the influence of active structures on the local stress field orientations. San Donato 1 well shows a minimum horizontal stress orientation of $\mathrm{N} 55 \pm 22^{\circ}$, in agreement with both the regional and local trends, the latter influenced by its vicinity to the Alto Tiberina Fault. Monte Civitello 1 well, in contrast, shows a quite different orientation, $\mathrm{N} 12 \pm 29^{\circ}$, due to its more eastward location and to the structures that it crosses. Although the angular difference between the two directions is within the error, to estimate the regional active stress field many borehole data should be analysed or smoothing maps should be evaluated; in fact, each borehole dataset could be influenced by local stress conditions that in some cases can be different from the regional trend. The two breakout orientations perfectly depict the regional extension along the axis of the Apennines and also the rotation of minimum horizontal stress moving eastward to the area where compression is predominant.
\end{abstract}

Key words active stress field - borehole breakout Colfiorito - northern Apennines

\section{Introduction}

This paper describes the regional presentday stress field and its local variations in the Umbria region. We discuss data already published relative to borehole breakout analysis performed in two deep wells (Monte Civitello 1 and San Donato 1) and show a new interpreta-

Mailing address: Dr. Maria Teresa Mariucci, Istituto Nazionale di Geofisica e Vulcanologia, Via di Vigna Murata 605, 00143 Roma, Italy; e-mail: mariucci@ingv.it tion that also considers earthquake focal mechanisms and geological structures (fig. 1). Although these deep wells are not exactly placed inside the epicentral area of the September-October 1997 Colfiorito sequence, we believe that the available data can be realistically used to improve and define the active stress field in the region. The Monte Civitello 1 (MC1) and San Donato 1 (SD1) wells were previous analyzed within a more extensive work relative to the stress map of central Italy (Mariucci et al., 1999) and afterwards the results were inserted in the Active Stress Map of Italy (Montone et al., 2004). Now we have re-analyzed the wells in more detail using newly available data from downhole logs. The stress orientations inferred from these two wells have been also compared with the stratigraphic record and with the main fault structures intersected by the boreholes. 


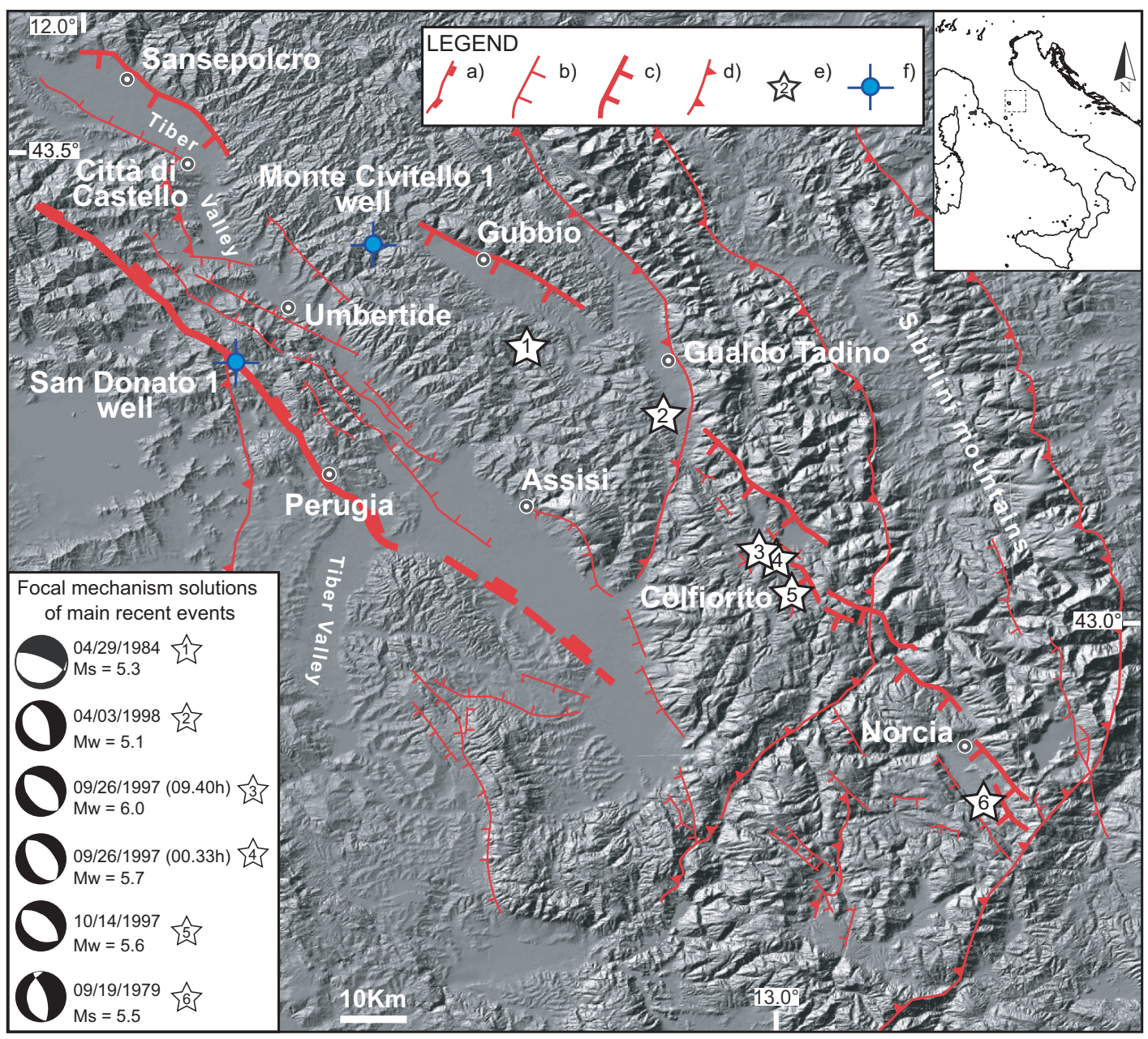

Fig. 1. Schematic structural map of the Umbria-Marche area (modified after Mirabella et al., 2004). Legend: a) Alto Tiberina fault; b) normal fault; c) Umbria fault system; d) thrust; e) earthquake $M>5.0$; f) wells analysed in this study. Focal mechanism solutions and magnitude: 1) 1984 Gubbio earthquake (Haessler et al., 1988); 2) 1998 Gualdo Tadino earthquake, and 3, 4, 5) 1997 Colfiorito sequence (Ekstrom et al., 1998); 6) 1979 Norcia earthquake (Deschamps et al., 1984).

Our methodology includes the identification of borehole breakouts in the downhole logs. Breakouts are enlargements that form on opposite sides of a borehole wall, and if the borehole axis is aligned with a principal stress axis then the breakouts are aligned along the direction of the minimum horizontal stress. It is generally accepted that breakouts derive from conjugate shear fractures which develop when a well is drilled in an anisotropic stress field (Bell and Gough, 1983; Zoback, 1992). Therefore, investigating breakouts and computing their average azimuth distribution allow us to get the orientation of the horizontal stress field around a well 
(Bell and Gough, 1983; Plumb and Hickmann, 1985; Zoback et al., 1985). We used four-arm caliper data to identify the borehole breakouts in our wells, and we assigned to each well a quality value, which is based on a combination of the breakout zone length, the standard deviation from the mean azimuth, the number of breakouts along the borehole, and the depth and lithology in which breakouts are detected.

Knowledge of the active stress field allows us to determine the behaviour of seismogenic structures and to define the seismotectonic zoning of a region. When the stress field in a region is well-known and faults are identified, it is possible to determine which of these faults are favourably oriented with respect to the stress field and which are more likely to slip in future earthquakes.

\section{Seismotectonic context}

This section provides an overview of information about the tectonic structure and the active stress field of the study area. We refer readers to the existing wide literature on this area and on the 1997 Colfiorito seismic sequence, as well as to the other papers in this volume and to a special issue of Journal of Seismology on Colfiorito earthquake (Amato and Cocco, 2000).

From seismological data the extension along the Apennines is very clear and oriented approximately perpendicular to the belt (Anderson and Jackson, 1987; Westaway, 1992; Pondrelli et al., 1995; Selvaggi 1998; Gasperini et al., 1999; Viti et al., 2001), in agreement with the NW-SE active normal faults (e.g. Valensise and Pantosti, 2001 and references therein). This agrees with the analysis of the strain field where extension was measured on both a local scale by repeated GPS campaigns (D'Agostino et al., 2001; Serpelloni et al., 2001) and a larger spatial and temporal scale (Hunstad et al., 2003). More recently, new data on the GPS velocity field for Italy and surrounding regions (Serpelloni et al., 2005) indicate an ENE-WSW extension in this sector, concentrated in a relatively narrow belt about $80 \mathrm{~km}$ wide. In contrast, the Adriatic foredeep and the southern Tuscany-Latium volcanic area display low deformation rates. These results are also confirmed by borehole breakout analysis (Mariucci et al., 1999; Montone et al., 2004) where a predominant extensional active stress field with a NE-SW minimum horizontal stress (Shmin) direction characterizes the Apennine belt and the Tyrrhenian coastal region. At the same latitude, along the outer front of the belt and the Adriatic offshore, Shmin is oriented NW-SE related to a compressive and, secondarily, strike-slip stress field (Mariucci et al., 1999; Montone et al., 2004, Pondrelli and Morelli, 2008 this volume).

From a tectonic point of view, this region in geologically recent times was characterized by an inversion of the tectonic stress field: the compression acting during the Late Miocene was replaced by extension starting in the Late Pliocene-Quaternary (e.g., Elter et al., 1975; Lavecchia et al., 1994). From a comparison of the recent tectonic evolution inferred from structural geology with the breakout results (Mariucci et al., 1999), it was argued that the coeval extension-compression pair, characteristic of the post-Tortonian evolution of the Apennines, has been migrating from late Miocene in this sector of the mountain belt. Moreover, the striking correspondence between the active compression front and the region with evidence of a remnant subducted slab (Selvaggi and Amato, 1992; Lucente et al., 1999) suggested that the migrating extension-compression pair is controlled by the progressive retreat of the slab (Mariucci et al., 1999).

The kinematics of the Quaternary and active faults is mainly related to normal faulting that affected the area since the early Pleistocene and was controlled by a constant NE-trending extensional stress field. This feature is also well evidenced in Colfiorito seismic sequence data that show almost all the focal mechanisms consistent with a present-day NE-SW trending extensional stress field (Amato et al., 1998; Ekstrom et al., 1998; Chiaraluce et al., 2003; 2005). The presence of important N-S shear zones in the area (Cello et al., 2003) does not seem related to the recognized active stress, but the seismic sequence seems confined between at least two major N-S shear zones (Cinti et al., 
2000; Collettini et al., 2005). These shear zones could represent «structural barriers» to the development of the seismic rupture planes, and therefore they may have controlled the dimension of the seismogenic structure (Meghraoui et al., 1999; Cinti et al., 2000).

\section{State of stress}

As already mentioned, in the Colfiorito area we have only two wells (SD1 and MC1) in which to perform breakout analysis. In a previous paper, a preliminary analysis, executed within a wider work with the analysis of 86 deep wells, indicated that Shmin is oriented NNESSW and ENE-WSW for SD1 and MC1 wells, respectively (Mariucci et al., 1999). These different orientations come from scattered data distributed along the logged intervals and do not seem to be simply related to the different tectonic units drilled by the wells. This large scatter was interpreted as due to the high degree of heterogeneity of the rocks in this region and to the great number of faults recognized in each well that might reorient the stress directions (Bell et al., 1992; Barton and Zoback, 1994). In this work we will try to understand the relationships existing between breakout directions, stratigraphy and crossed faults.

\subsection{Monte Civitello 1 breakout analysis}

A detailed analysis has been performed on Monte Civitello 1 well logs. The borehole, drilled by AGIP in 1988-89, is $5600 \mathrm{~m}$ deep with a deviation from vertical less than $7^{\circ}$. The stratigraphy of the well is composed of: Miocene flysch («Marnoso Arenacea» fm) in the interval 0-1076 $\mathrm{m}$; the Umbria-Marche Meso-Cenozoic pelagic sequence (1076-2220 $\mathrm{m})$; the Umbria-Marche platform carbonates $(2220-2841 \mathrm{~m})$; the triassic evaporites («Anidriti di Burano» fm; Martinis and Pieri, 1964) from 2841 to $5600 \mathrm{~m}$ (fig. 2a). The well is located close to the Gubbio tectonic structure in the north-western sector of the Gubbio basin (fig. 1). It intersects several faults between 300 $\mathrm{m}$ and $1500 \mathrm{~m}$, whereas only two main fault structures are recognized in its deepest part. These latter features could be the Gubbio fault and the Alto Tiberina fault. A previous analysis of this well (Mariucci et al., 1999) gave a minimum horizontal stress direction of $\mathrm{N} 11 \pm 29^{\circ}$ for a total breakout length of $1431 \mathrm{~m}$, with overall low data quality (equal to D).

In this paper we re-analyzed the breakout data comparing them with the available geophysical logs (sonic, gamma ray, resistivity, dip strata), which previously were not considered, and the stratigraphy and structural setting of this area. We have taken into account the depth interval between 248 and $5559 \mathrm{~m}$, and found breakouts from 500 to $5541 \mathrm{~m}$. The complete analysis, including all of the breakout zones, shows a Shmin N $12 \pm 29^{\circ}$ with a total breakout length of $1397 \mathrm{~m}$ and D data quality (fig. 2c). The breakout zones are present throughtout the well showing a long deep interval with the same breakout orientations, whereas in the shallow part systematic breakout rotations close to the faults can be observed (fig. 2, see inset). For this reason we analysed the breakout data split into four different stratigraphic intervals (fig. 2b). In the Umbria Miocene turbidites the analysis (data from 500 down to $1060 \mathrm{~m}$ ) shows a Shmin N59 $\pm 29^{\circ}$ for $252 \mathrm{~m}$ total length of breakout zones, to which we assigned a D data quality. In the data interval between 1209 and $2103 \mathrm{~m}$, within the pelagic formations, the analysis shows a Shmin N $344 \pm 36^{\circ}$ for a total length of $323 \mathrm{~m}$ of breakouts with a D quality. The rose plot for the interval between 2234 and $2794 \mathrm{~m}$ (carbonate platform units) points out a Shmin N10 $\pm 4^{\circ}$, with a length of breakouts of $113 \mathrm{~m}$ and $\mathrm{B}$ quality. The last rose plot from the «Burano» Triassic evaporite formation (data from 2870 to $5541 \mathrm{~m}$ ) shows a Shmin N9 $\pm 18^{\circ}$ for a total length of $709 \mathrm{~m}$, with B quality. These diagrams highlight the strong difference between the shallow and the deeper part of the well. In fact, while in the deeper formations («Burano» and carbonate platform units) Shmin orientations are well constrained around a N-S direction, with a low standard deviation (about $11^{\circ}$ ) and a very high total length of breakout zones $(822 \mathrm{~m})$, in the upper part of the hole (turbidites and pelagic sequences) a high degree of scattering of breakout orientations is 
MONTE CIVITELLO 1 WELL

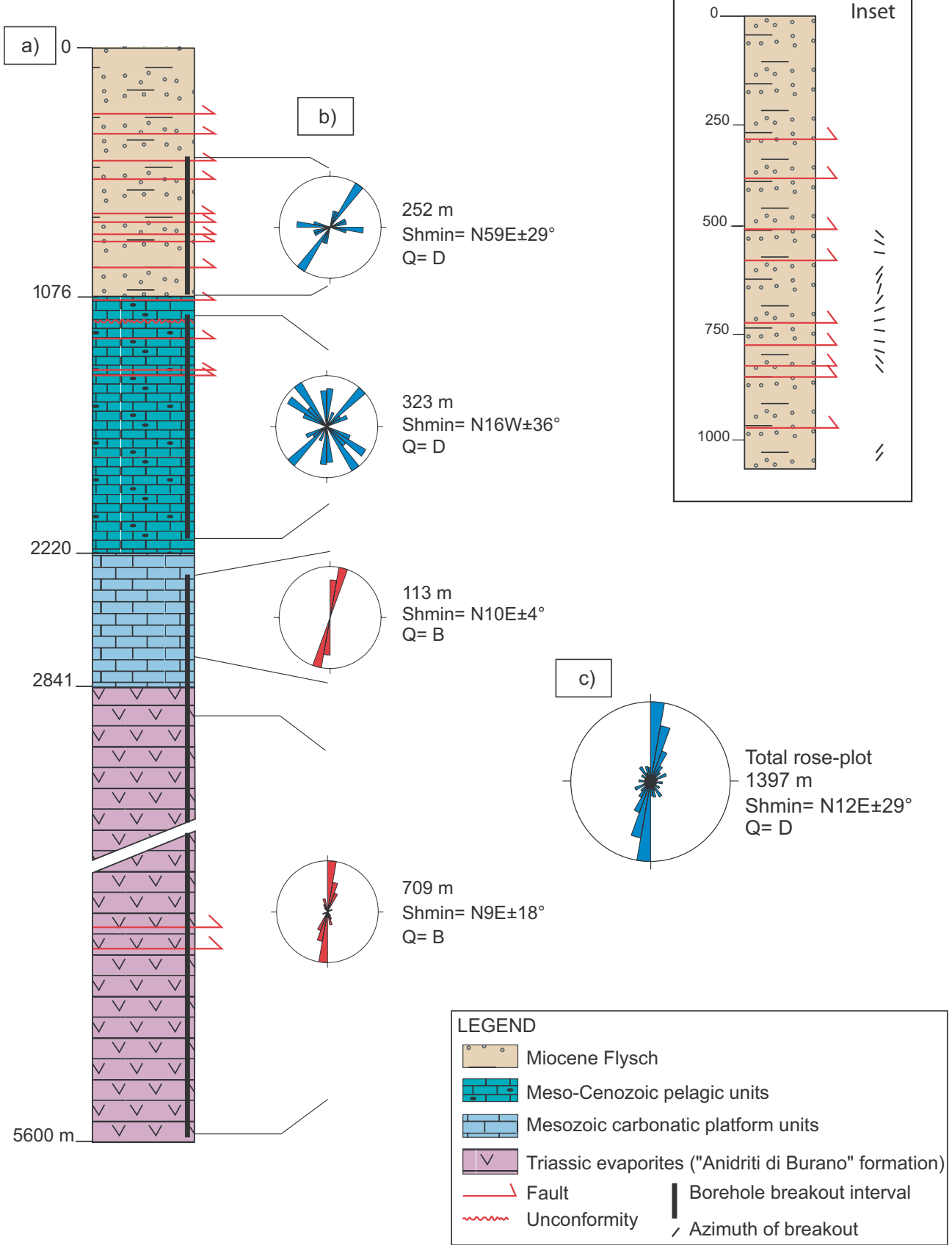

Fig. 2a-c. Monte Civitello 1 well analysis: a) stratigraphic sketch; b) Shmin from breakout data for different units; c) Shmin from all breakout data. Beside each rose plot: breakout length, Shmin orientation and standard deviation, quality assigned to the result. In the inset details on the Shmin breakout orientations for the first $1000 \mathrm{~m}$. 
evident, with standard deviation values greater than $30^{\circ}$ for a total length of $575 \mathrm{~m}$.

A possible explanation of these non-homogeneous orientations is related to the stratigraphic sequences characterized by thin layers of marls, sandstones and clays that could affect the breakout orientations. Otherwise the scattered orientations can be due to the presence of the above-mentioned faults that cross the well in the range between 300 and $1500 \mathrm{~m}$. As it is possible to observe in the inset of fig. 2, this last explanation seems to be the most convincing. Breakout orientations seem to rotate in proximity to the faults, tending to reorient in the perpendicular direction with respect to the main Shmin trend (Bell et al., 1992; Barton and Zoback, 1994).

Taking into account that: i) the faults seem to reorient the stress in the shallow part of the well, ii) the result achieved from the total analysis is mainly influenced by the deeper part of the well (about 60\%), and iii) bedding does not affect breakout orientations, Shmin inferred from this well can be a reliable estimate of the regional stress direction, even though its quality (D) usually is not used in stress maps.

\subsection{San Donato 1 breakout analysis}

A detailed analysis has been performed on SD1 well logs. The borehole, $4763 \mathrm{~m}$ deep and with a deviation from vertical less than $4^{\circ}$ was drilled by SNIA-BPD in 1983-84 and is located about $20 \mathrm{~km}$ south-west of the MC1 well (fig. 1). It is in a peculiar position with respect to one of the major features of northern Apennines: it is very close to the Alto Tiberina fault. Indeed, this low angle normal fault is crossed at $326 \mathrm{~m}$ depth by SD1, juxtaposing the «Marnoso Arenacea» Miocene turbidite sequence directly on the «Anidriti di Burano» Triassic sequence down to $3030 \mathrm{~m}$. From $3030 \mathrm{~m}$ to $4485 \mathrm{~m}$ the well penetrates metamorphic basement («Verrucano» fm) which lies, with a tectonic contact, on «Anidriti di Burano» unit, where the borehole ends without crossing any Umbria-Marche marine unit, unlike MC1 (fig. 3a).

SD1 was previously analyzed (Mariucci et al., 1999) giving a resulting Shmin orientation of
$\mathrm{N} 77 \pm 23^{\circ}$ with a data quality equal to $\mathrm{C}$ (medium quality). No correlation between breakout orientations and stratigraphy had been found, and the breakout orientations were distributed along the well showing a prevalent mean orientation about ENE-WSW and secondarily NE-SW.

Now we have had the chance to reanalyze this well comparing the available geophysical logs, previously not considered (gamma ray, resistivity) with the stratigraphy and with the structural setting of this area. We analysed the interval between 466 and $4062 \mathrm{~m}$ where we found breakout zones from 1550 to $4022 \mathrm{~m}$. The first part of the logged interval does not show breakout zones, and the well deviation from the vertical often is too low (less than $0.5^{\circ}$ ) and not suitable to obtain reliable breakout orientations. The comparison with gamma ray, resistivity and stratigraphy allowed us to constrain the Shmin orientation in the whole borehole: $\mathrm{N} 55 \pm 22^{\circ}$ with C data quality for a total length of breakout zones equal to $547 \mathrm{~m}$ (fig. $3 \mathrm{c})$. We have performed the breakout analysis for each main stratigraphic interval separately (fig. 3b) showing good qualities (B) and roughly the same Shmin orientation. The analysis in the deep Triassic evaporites (breakouts from 1550 down to $2055 \mathrm{~m}$ ) shows a Shmin $\mathrm{N} 38 \pm 18^{\circ}$ for a total breakout length of $176 \mathrm{~m}$. This result is in agreement with the Shmin orientation $\mathrm{N} 63 \pm 20^{\circ}$ relative to the «Verrucano» metamorphic basement, although it shows a slight difference of about $20^{\circ}$, within the error of the results. The latter analysis identified breakout zones between 3128 and $4022 \mathrm{~m}$, for a total breakout length of $371 \mathrm{~m}$.

\section{Discussion and Conclusions}

The Shmin orientation inferred from MC1, about N-S, differs strongly from the regional Shmin trend, about NE-SW (Montone et al., 2004), and suggests the influence of active structures consistent with this stress orientation, such as E-W normal faults or strike slip faults perpendicular to the belt or N-S faults. The former interpretation can be related to a bend of NW-SE normal faults, as recognized on the Gubbio fault both at the surface and at 


\section{SAN DONATO 1 WELL}

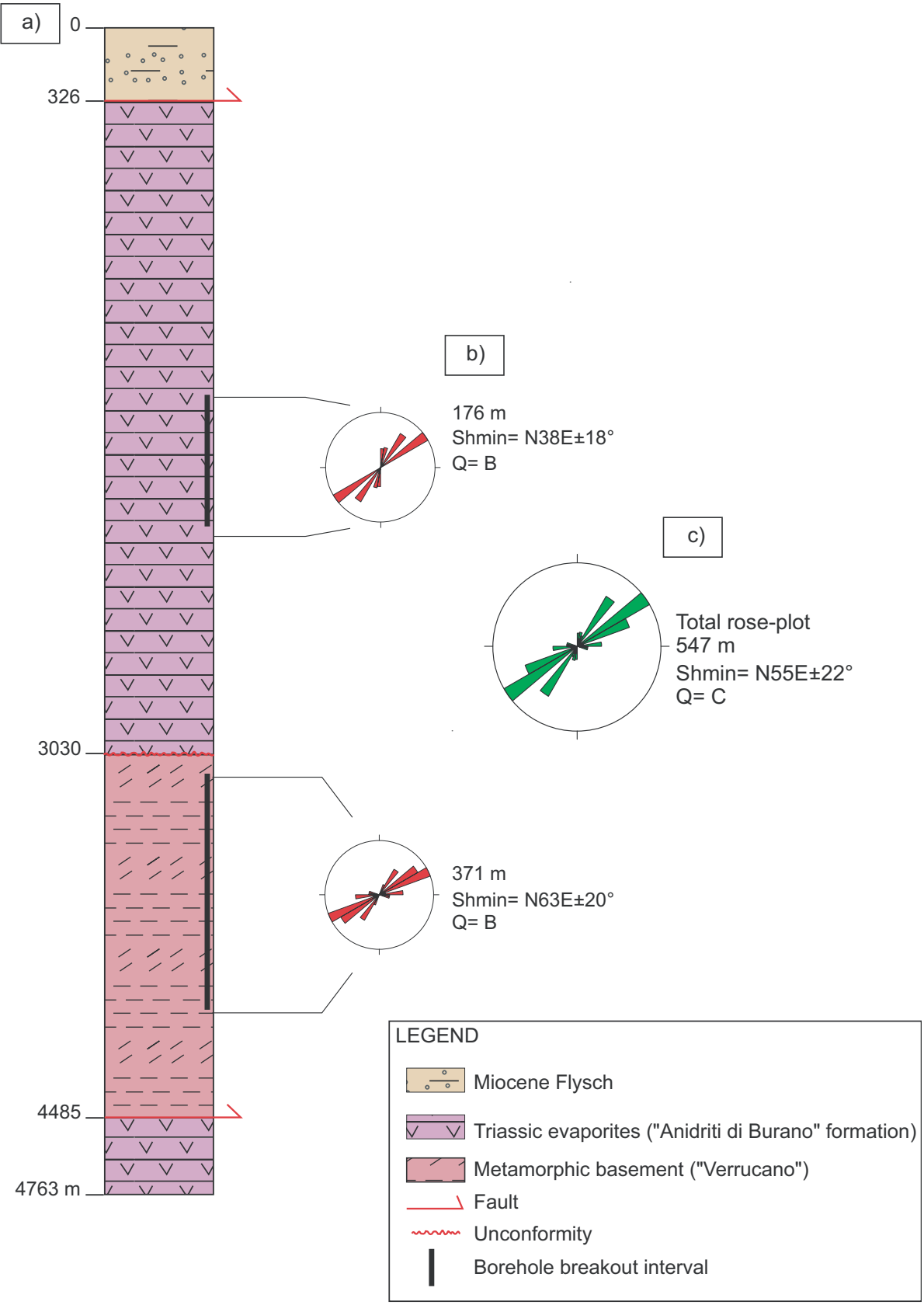

Fig. 3a-c. San Donato 1 well analysis: a) stratigraphic sketch; b) Shmin from breakout data for different units; c) Shmin from all breakout data. Beside each rose plot: breakout length, Shmin orientation and standard deviation, quality assigned to the result. 
depth (Mirabella et al., 2004 and references therein). It can be argued that a similar structure could also be present in the area of the MC1 well. This interpretation is also supported by the focal mechanism of 1984 Gubbio earthquake computed by Haessler et al. (1988), where the fault plane dipping toward south is about E-W oriented. Although the mainshock occurred at the southern edge of the sequence (Collettini et al., 2003), most of the seismic events are located in a narrow belt corresponding to the bend area of the Gubbio fault (Mirabella et al., 2004), suggesting that the rupture may have occurred on the E-W oriented portion of the fault plane. This is in agreement with the Haessler et al. (1988) fault plane solution and with a Shmin about N-S oriented, as inferred from our data. A fault with a bend can represent the remnant of a segmented structure evolved to form a single fault (e.g. Cartwright et al., 1995 and references therein). The second hypothesis is that the stress orientation could be due to the presence of a transfer fault that separates two NW-SE oriented structures (Barchi et al., 1998). In the northern Apennines there are some seismic events characterized by T-axes about N-S that would support our breakout data (fig. 4).

After the detailed revision of the whole SD1 well dataset (digital and paper dipmeter logs, stratigraphy, gamma ray and resistivity) we believe that the Shmin orientation $\mathrm{N} 55 \mathrm{E} \pm 22^{\circ}$ is more reliable than the previous result that gave a Shmin orientation $\mathrm{N} 77 \pm 23^{\circ}$. The Shmin

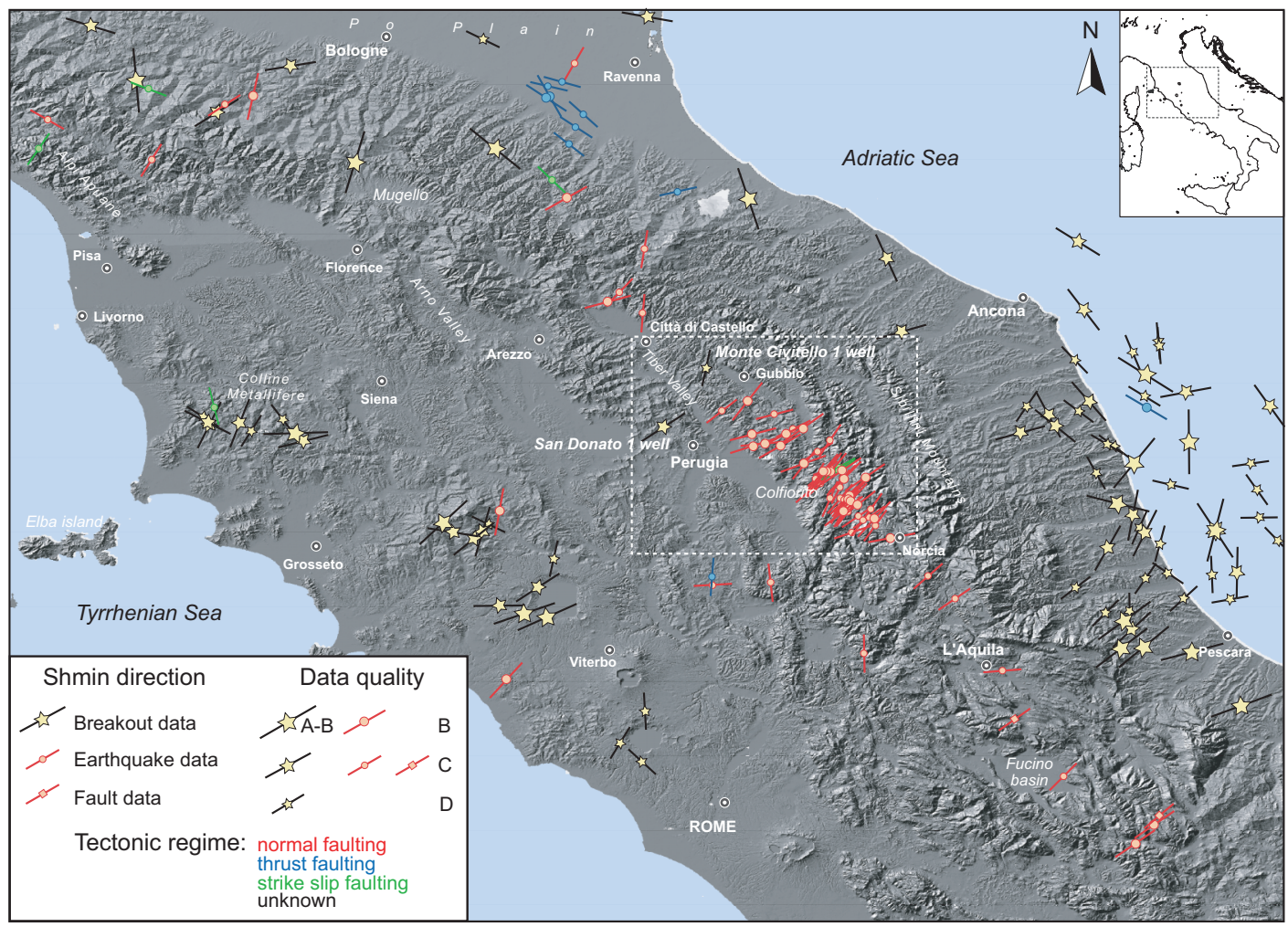

Fig. 4. Active stress map of central Italy (Shmin direction) with all data quality (modified after Montone et al., 2004). The dashed square is the area of fig. 1. 
$\mathrm{N} 55 \mathrm{E} \pm 22^{\circ}$ is much more in agreement with data by earthquake focal mechanisms in this area, even if slightly rotated toward an E-W direction. We believe that this difference can be due to the location of the well, very close to the Alto Tiberina Fault that has a mean direction about NNW-SSE. In this case the presence of an important tectonic feature slightly rotates the active stress field in the direction of the minimum horizontal stress inside a very strong extensional stress regime. An extensional tectonic regime in this area was also confirmed by the estimate from borehole breakout occurrence at depth in SD1 (Mariucci and Müller, 2003).

The main lesson learned is that a detailed analysis in a single well or in two wells in the same area can give strong indications of the local stress variations. However, we wish to emphasize that only two data points cannot adequately depict the regional stress field, and more data are needed or smoothed maps should be built with other information in order to get a reliable and well-constrained mean orientation of a large area.

Notwithstanding the slightly different Shmin orientations in the two boreholes, within the error, both results give information about the regional active stress field. Indeed, a rotation of Shmin toward the foredeep, from NE-SW to NNE-SSW, is coherent in an intermediate area linking the extensional belt with the outer front of the Apennines, where compression is still active and Shmin trend is NW-SE (fig. 4).

\section{Acknowledgments}

Many thanks are due to ENI S.p.A. because without their collaboration this work, as all that relative to this topic, would have been impossible. We are grateful to the reviewers F. Fernández-Ibáñez and F. Mirabella for the helpful comments and suggestions. We thank A. DayLewis for improving the English. This work has been developed within the FIRB-MIUR Project «Research and Development of New Technologies for Protection and Defense of Territory from Natural Risks», W.P. C3 «Crustal Imaging in Italy» coordinated by $\mathrm{P}$. Montone.

\section{REFERENCES}

Amato, A. and M. Cocco (Eds.) (2000): Special Issue on 1997 Umbria-Marche earthquakes, J. Seismol., 4 (4), October 2000.

AмAто, A. et al. (1998): The 1997 Umbria-Marche, Italy, earthquake sequence: a first look at the main shocks and aftershocks, Geophys. Res. Let., 25, 15, 2861-2864.

ANDERSON, H. and J. JACKSON (1987): Active tectonics of the Adriatic region, Geophys. J. R. Astron. Soc., 91, 937-987.

Barchi M.R., A. De Feyter, M.B. Magnani, G. Minelli, G. Pialli and B.M. Sotera (1998): The structural style of the Umbria-Marche fold and thrust belt, Mem. Soc. Geol. It., 52, 557-578.

BARTON C.A. and ZoBACK M.D. (1994): Stress perturbations associated with active faults penetrated by boreholes: possible evidence for near-complete stress drop and a new technique for stress magnitude measurement, J. Geophys. Res., 99 (B5), 9373-9390.

Bell, J.S. and D.I. Gough (1983): The use of borehole breakouts in the study of crustal stress, in Hydraulic Fracturing Stress Measurements, edited by M.D. Zoback and B.C. Haimson (Nat. Acad. Press, Washington, D.C.), 201-209.

Bell, J.S., G. Caillet and J. Adams (1992): Attempts to detect open fractures and non-sealing faults with dipmeter logs, in Geological applications of wireline logs II, edited by A. Hurst, C.M. GRIFFITHS and P.F. WoRthington, Geol. Soc. Spec. Publ., 65, 211-220.

Cartwright, J.A., B.D. Trudgill and C.S. Mansfield (1995): Fault growth by segment linkage: an explanation for scatter in maximum displacement and trace length data from Canyonlands Grabens of SE Utah, $J$. Struct. Geol., 17 (9), 1319-1326.

Cello, G., S. Mazzoli, E. Tondi and E. Turco (2003): Active tectonics in the central Apennines and possible implications for seismic hazard analysis in peninsular Italy, Tectonophysics, 272 (1), 43-68, doi: 10.1016/S0040-1951(96)00275-2.

Chiaraluce, L., W. Ellsworth, C. Chiarabba and M. Cocco (2003): Imaging the complexity of an active complex normal fault system: the 1997 Colfiorito (central Italy) case study, J. Geophys. Res., 108 (B6), 2294.

Chiaraluce, L., M. Barchi, C. Collettini, F. Mirabella and S. PUCCI (2005): Connecting seismically active normal faults with Quaternary geological structures in a complex extensional environment: The Colfiorito 1997 case history (northern Apennines, Italy), Tectonics, 24, TC1002, doi:10.1029/2004 TC001627.

Cinti, F.R., L. Cucci, F. Marra and P. Montone (2000): The 1997 Umbria-Marche earthquakes (Italy): relation between the surface tectonic breaks and the area of deformation, J. Seismol., 4, 333-343.

Collettini, C. , M.R. Barchi, L. Chiaraluce F. MirabelLA and S. PUCCI (2003): The Gubbio fault: can different methods give pictures of the same object?, J. Geodyn., 36, 51-66, doi:10.1016/S0264-3707(03)00038-3.

Collettini, C., L. Chiaraluce, S. Pucci, M.R. Barchi and M. CoCCO (2005): Looking at fault reactivation matching structural geology and seismological data, J. Struct. Geol., 27, 937-942, doi: 10.1016/j.jsg.2004.10.016.

D'Agostino, N., R. Giuliani, M. Mattone and L. Bonci 
(2001): Active crustal extension in the central Apennines (Italy) inferred from GPS measurements in the interval 1994-1999, Geophys. Res. Lett., 28 (10), 2121-2124.

Deschamps A., G. IAnNaccone and R. Scarpa (1984): The Umbrian earthquake (Italy) of 19 September 1979, Annals Geophisicae, 2 (1), 29-36.

Ekström, G., A. Morelli, E. Boschi and A.M. DziewonsKI (1998): Moment tensor analysis of the central Italy earthquake sequence of September-October 1997, Geophys. Res. Lett., 25, 1971-1974.

Elter, P., G. Giglia, M. Tongiorgi and L. Trevisan (1975): Tensional and compressional areas in the recent evolution of the Northern Apennines, Boll. Geof. Teor. Appl., XVII, 65.

Gasperini, P., F. Bernardini, G. Valensise and E. Boschi (1999): Defining seismogenic sources from historical earthquake felt reports, Bull. Seismol. Soc. Am., 89 (1), 94-110.

Haessler, H., R. Gaulon, L. Rivera, R. Console, M. Frogneux, G. Gasparini, L. Martel, G. Patau, M. SiCiliano and A. Cisternas (1988): The Perugia (Italy) earthquake of 29 April 1984: a microearthquake survey, Bull. Seismol. Soc. Am., 78, 1948-1964.

Hunstad, I., G. Selvaggi, N. D'agostino, P. England, P. Clarke, and M. Pierozzi (2003): Geodetic strain in peninsular Italy between 1875 and 2001, Geophys. Res. Lett., 30 (4), 1181, doi:10.1029/2002GL016447.

Lavecchia, G., F. Brozzetti, M. Barchi, M. Menichetti, and J.V.A. KeLler (1994): Seismotectonic zoning in East-Central Italy deduced from the analysis of the Neogene to present deformations and related stress fields, Bull. Geol. Soc. Am., 106, 1107-1120.

Lucente, F.P., C. Chiarabba, G.B. Cimini and D. Giardini (1999): Tomographic constraints on the geodynamic evolution of the Italian Region, J. Geophys. Res., 104, 20307- 20327.

MariuCCI, M.T., A. Amato and P. Montone (1999): Recent tectonic evolution and present stress in the northern Apennines, Tectonics, 18, 108-118.

MARIUCCI, M.T. and B. MüLLER (2003): The tectonic regime in Italy inferred from borehole breakout data, Tectonophysics, 361, 21-35.

MARTINIs, B. and M. PIERI (1964): Alcune notizie sulla formazione evaporitica dell'Italia centrale e meridionale, Mem. Soc. Geol. It., 4, 649-678.

Meghraoui, M., V. Bosi and T. Camelbeec (1999): Fault fragment control in the 1997 Umbria-Marche, central Italy, earthquake sequence, Geophys. Res. Lett., 26 (8), 1069-1072.

Mirabella, F., M.G. Ciaccio, M.R. Barchi and S. Mer-
LINI (2004): The Gubbio normal fault (Central Italy): geometry, displacement distribution and tectonic evolution, J. Struct. Geol., 26, 2233-2249, doi: 10.1016/j.jsg.2004.06.009.

Montone, P., M.T. Mariucci, S. Pondrelli and A. Amato (2004): An improved stress map for Italy and surrounding regions (central Mediterranean), J. Geophys. Res., 109, B10410, doi:10.1029/2003JB002703.

Plumb, R.A. and S.H. HickmanN (1985): Stress-induced borehole elongation: a comparison between dipmeter and the borehole televiewer in the Auburn geothermal well, J. Geophys. Res., 90, 5513-5521.

Pondrelli, S., A. Morelli and E. Boschi (1995): Seismic deformation in the Mediterranean area estimated by moment tensor summation, Geophys. J. Int., 122, 938-952.

SelvaGgi, G. (1998): Spatial distribution of horizontal seismic strain in the Apennines from historical earthquakes, Annali di Geofisica, 41 (2), 241-251.

SelvagGi, G., and A. Amato (1992): Subcrustal earthquakes in the northern Apennines (Italy): Evidence for a still active subduction?, Geophys. Res. Lett., 19, 2127-2130.

Serpelloni, E., M. Anzidei, P. Baldi, G. Casula, A. GalVANI, A. PESCI and F. RiguZZI (2001): Geodetic deformations in the Central-Southern Apennines (Italy) from repeated GPS surveys, Annals of Geophysics, $\mathbf{4 4}$ (3), 627-647.

Serpelloni, E., M. Anzidei P. Baldi G. Casula and A. GaLvani (2005): Crustal velocity and strain-rate fields in Italy and surrounding regions: new results from the analysis of permanent and non-permanent GPS networks, Geophys. J. Int., 161 (3), 861-880, doi: 10.1111/j.1365-246X.2005.02618.x.

Valensise, G. and D. PAntosti (Eds.) (2001): Database of potential sources for earthquakes larger than M 5.5 in Italy, Annali di Geofisica, suppl. to vol. 44 (4), 180, (with CD-ROM).

Viti, M., D. Albarello and E. Mantovani (2001): Classification of seismic strain estimates in the Mediterranean region from a 'bootstrap' approach, Geophys. $J$. Int., 146, 399-415.

WestaWAY, R. (1992): Seismic moment summation for historical earthquakes in Italy: tectonic implications, $J$. Geophys. Res., 97, 15437-15464.

Zoback, M.D., D. Moos, L. MASTIN and R.N. ANDERSON (1985): Well bore breakouts and in situ stress, J. Geophys. Res., 90, 5523-5530.

ZoвACK, M.L. (1992): First and second order patterns of stress in the lithosphere: the World Stress Map Project, J. Geophys. Res., 97, 11703-11728. 